\title{
Systemic lupus erythematosus: 2 case reports from Eritrea
}

Almaz Zerai M.D. Sembel Hospital, Asmara, Eritrea

Systemic Lupus Erythematosus is an autoimmune disorder, occurring predominantly in women during reproductive age and characterized by the presence of antibodies in the serum against the nuclear components (ANA), leading to inflammation in kidney, brain, and skin manifestations.

The diversity of the disease the clinical presentation with the accumulation of manifestations over time and the fluctuant disease course challenges many clinicians. Two cases of Systemic Lupus Erythematosus with different manifestations revealing, challenges in diagnostic, treatment, follow up and bleak prognosis are presented.

\section{Introduction}

Systemic Lupus Erythematosus is a chronic inflammatory disease of unknown etiology, but is probably of multi-factorial origin, including a variable genetic predisposition and environmental factors that trigger the disease. It is much common among certain races including population groups including Africans, Indians, and Polynesians and in black women in USA. Known environmental triggers include: ultraviolet light and drugs such as hydralazine, chlorpromazine and methyldopa. The characteristic of Systemic Lupus Erythematosus is the female predominance approximately 9:1 and the onset during the reproductive years.

The disease is characterized by a widespread vasculitis affecting capillaries, arterioles and venules. Any organ can be affected by SLE in which tissues and cells are damaged by pathogenic antibodies and immune complexes. Several symptoms of mucocutaneous, musculoskeletal, renal and central nervous system, in addition nonspecific features such as fatigue, fever, and weight loss dominate the clinical pictures making the disease qualify into the clique of diseases of master of mimicry. The presence of auto antibodies is useful for the diagnosis and the pattern of auto antibodies may help to predict the clinical manifestations. Anti double stand DNA antibodies are useful along or with changes in complement levels.

\section{Case $A$}

A 14 years old girl, student from Asmara, admitted to the Sembel Hospital on 22/5/07, because of fever, weight loss and generalized body weakness. She was healthy until one year back, when she presented with allergic rhinitis, skin rash, and intranasal ulceration, which subsided without treatment or after taking antihistamine drugs. After several months she presented headache, fever, arthralgia of carpal, metacarpal and knee joints bilaterally. Thereafter, she had anorexia, mucosal ulceration, weight loss, and fatigue making her stop to the school and for five months was bed ridden.

On physical examination she was pale and emaciated with a body weight of $30 \mathrm{~kg}$, blood pressure of $80 / 60 \mathrm{mmHg}$, pulse of $134 / \mathrm{min}$, body temperature of $37^{\circ} \mathrm{C}$, and $\mathrm{O}_{2}$ saturation of $86 \%$.

The muco-cutaneous lesions included a butterfly like exanthema on her nose and cheeks, edematous lips inflamed and angular chelitis. Examining her oral mucosa she had a small ulceration on the soft palate, pigmented spots were on her posterior chest and on both legs, a small bed sore on her lower back.

With respect to the musculoskeletal features, painful knee and carpal joints, the patient could not stand.

The cardiopulmonary features were mild crepitations and decreased breath sound on the left lower lung filed, tachycardia and apical systolic murmur.

The abnormal laboratory examination were a hemoglobin of $5 \mathrm{~g} \%$ hematocrit of $17 \%$, platelet count of 176000, ESR of $141 \mathrm{~mm} / \mathrm{hr}$, a left sided pleural effusion on and mild brain atrophy on MRI.

Nine days after admission on 01/06/07 I had the result of ANA complement anti-DNA and protein electrophoresis which were as follows; albumin 1.4, globulin 0,3, a2- globulin 1, b- globulin 0.6, $\gamma$ - globulin 3.3 no monoclonal peak, polyclonal increase in $\gamma$ globulins.

ANA $1 / 2560, C_{3} 40,7$ (NR=83-185), $C_{4}=18$ (12-54). Anti double stranded DNA antibodies were positive (Crithidia).

Systemic lupus erythematosus the most likely diagnosis in this case, but I didn't have the appropriate serologic tests and was no possibility to have it in one or two days. This girl needed very aggressive treatment for systemic lupus erythematosus probably with a combination of drugs, and monitoring of the serum complement and double stranded DNA antibody levels.

She was immediately started on corticosteroid therapy (prednisolone $40 \mathrm{mg} /$ day). The patient had very good response. After two days she could open her mouth and she could eat, started walking and could go to the toilet by herself. The third day she presented with seizures witnessed by the nurses and subsided without medication. As her mother informed us was not the first time, she had similar signs during the night also at home. Once started on phenobarbital there was no other similar attack.

The patient was discharge in good condition on prednisolone $40 \mathrm{mg}$ and phenobarbital $30 \mathrm{mg}$ orally twice/ day.

Two weeks after she had been discharged she returned in bad condition because she discontinued 
her medication against medical advice.

She was restarted the medication, but the patient after few months she developed renal failure and signs of psychosis so she advised to go abroad where she could be evaluated by a rheumatologist and nephrologists. She went to Sudan and after two months her father told me that she had passed away.

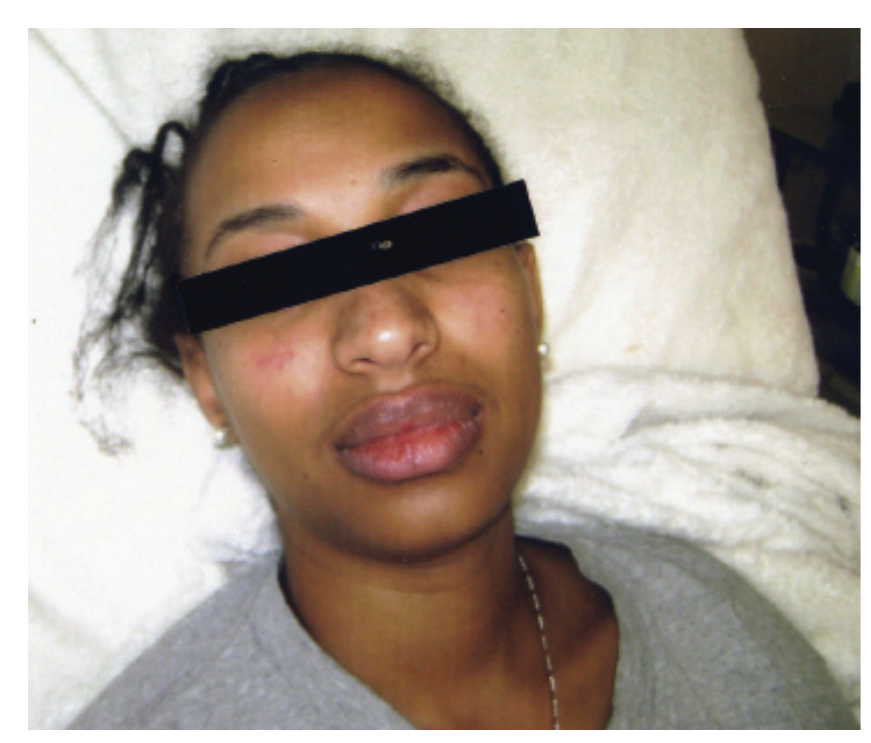

\section{Case B}

Systemic Lupus Erythematosis and Vasculitis

A 23 year young lady admitted to the Sembel Hospital because of severe arthralgia, myalgia, and dificulties to do her daily activities. The symptoms began one year back and she was taking non steroid anti-inflammatory drugs without any respond.

On physical examination, she was sick looking with swollen and inflamed lips butterfly rash, palmar erythema, Raynaud's phenomenon, livedo reticularis, purpuric exanthema and two vasculitic lesions on the left leg.

Laboratory findings done around one year before, at that time she had pancytopenia, WBC 2300, hemoglobin 10, Hematocrete $32 \%$, platelets71000, ESR 45 mm/hour, and proteinuria. The blood test on admission showed leucopenia $\mathrm{WBC}=1900$, thrombocytopenia 46,000, hemoglobin 11 and hematocrit 36\%, and ESR 76mm/ hour.

The patient was started on corticosteroid and hydroxichloroquine and blood sent to USA for the appropriate tests.

After few days we had the results and $A N A=1 / 5120$, speckled $\mathrm{C} 3=44(\mathrm{~N} . \mathrm{R}=83-185) \mathrm{C} 4=7(\mathrm{~N} . \mathrm{R}=12-54)$ a-DNA antibodies +ve (crithidia)

This patient was followed to the OPD for 6 months and she had good improvement, but after starting the tapering of the corticosteroid the $n$ we have flaring of the disease especially of the vasculitis and the vasculitic leg lesions. Finally she go to abroad and there is no any information about her condition.

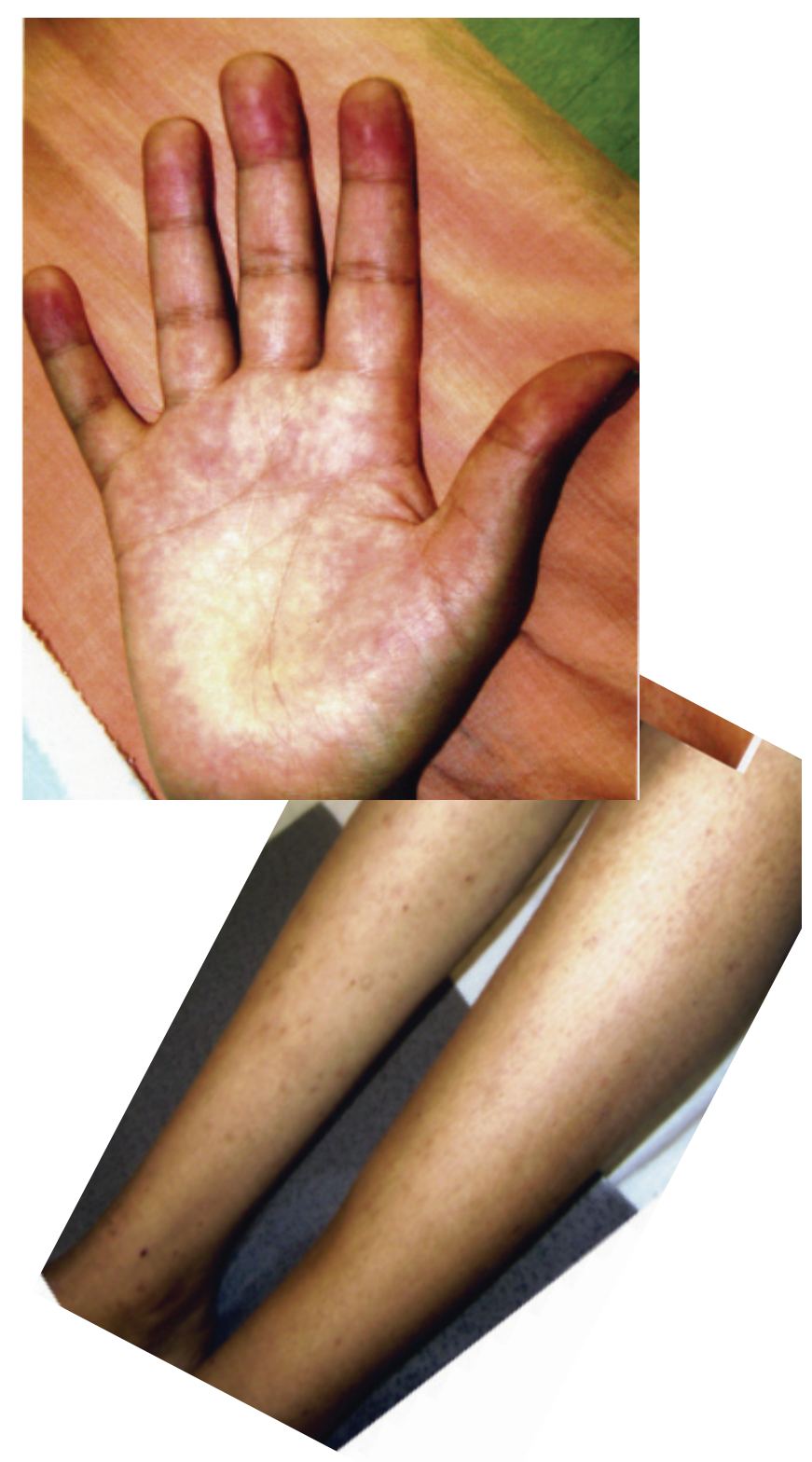

\section{Discussion}

Systemic lupus Erythematosus is a disease of young women, can display familial aggregation with higher frequency among first degree relatives of patients, in approximately $25 \%$ to $50 \%$ of monozygotic twins and $5 \%$ of dizygotic twins ${ }^{1}$. The hallmark of Systemic Lupus Erythematosus is its diversity of presentations. The symptoms and signs may start abruptly or may take months or years before the diagnosis and can be confirmed by the appearance of additional features. The patients with SLE can enjoy periods of extended remission without clinical activity and even the disappearance of antinuclear antibodies. ${ }^{2}$

The etiology of the disease is unknown but extensive investigations have been done to explain the mechanisms responsible for the tissue damage. Major areas of study include circulating immune complexes and complement metabolism cell mediated immunity. Acknowledging the complexity of this disease is broad differential diagnosis and the need to develop better and more specific therapies. The American College of Rheumatology (ACR) has designated 11 diagnostic criteria (Table 1). ${ }^{1}$ 
Table 1: Revised criteria for the diagnosis of systemic lupus erythematosus

\begin{tabular}{|c|c|}
\hline Criterion & Definition \\
\hline $\begin{array}{l}\text { Malar } \\
\text { rash }\end{array}$ & $\begin{array}{l}\text { Fixed erythema, flat or raised, over the malar } \\
\text { eminence, tending to spare the nasolabial } \\
\text { folds }\end{array}$ \\
\hline $\begin{array}{l}\text { Discoid } \\
\text { rash }\end{array}$ & $\begin{array}{l}\text { Erythematous raised patches with adherent } \\
\text { keratotic scaling and follicular plugging: } \\
\text { atrophic scarring may occur in older lesions }\end{array}$ \\
\hline $\begin{array}{l}\text { Photo } \\
\text { sensitivity }\end{array}$ & $\begin{array}{l}\text { Skin rash as a result of unusual reaction to } \\
\text { sunlight, by patient history or physician } \\
\text { observation }\end{array}$ \\
\hline Oral ulcers & $\begin{array}{l}\text { Oral or nasopharyngeal ulceration, usually } \\
\text { painless, observed by a physician }\end{array}$ \\
\hline Arthritis & $\begin{array}{l}\text { Nonerosive arthritis involving two or more } \\
\text { peripheral joints, characterized by tenderness, } \\
\text { swelling or effusion }\end{array}$ \\
\hline Serositis & $\begin{array}{l}\text { 1.Pleuritis; convincing history of pleuritic pain } \\
\text { or rub heard by physician } \\
\text { 2. or evidence of pleural effusion OR } \\
\text { Pericarditis; documented by electrocardiogram } \\
\text { or rub or evidence of pericardial effusion }\end{array}$ \\
\hline $\begin{array}{l}\text { Renal } \\
\text { disorder }\end{array}$ & $\begin{array}{l}\text { ( a ) Persistent proteinuria }>500 \mathrm{mg} \text { per day or } \\
>3+\text { if quantitation not performed OR } \\
\text { ( b) Cellular casts: maybe red cell, hemoglobin, } \\
\text { granular, tubular or mixed }\end{array}$ \\
\hline $\begin{array}{l}\text { Neuro } \\
\text { logic } \\
\text { disorder }\end{array}$ & $\begin{array}{l}\text { ( a ) seizures: in the absence of offending drugs } \\
\text { or known metabolic derangement; e.g. uremia, } \\
\text { ketoacidosis, or electrolyte imbalance OR } \\
\text { ( b ) psychosis: in the absence of offending } \\
\text { drugs or known metabolic derangement; e.g. } \\
\text { uremia, ketoacidosis, or electrolyte imbaiance }\end{array}$ \\
\hline $\begin{array}{l}\text { Hemato } \\
\text { logic } \\
\text { disorder }\end{array}$ & 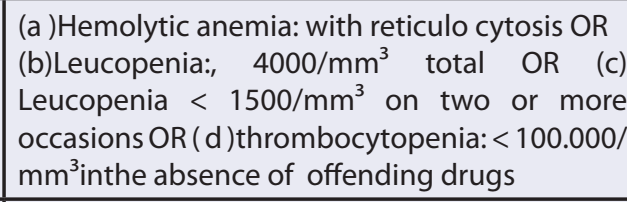 \\
\hline $\begin{array}{l}\text { Immuno } \\
\text { logic } \\
\text { disorder }\end{array}$ & $\begin{array}{l}\text { ( a ) Anti-DNA: antibody to native DNA in } \\
\text { abnormal titer OR } \\
\text { ( b ) Anti-: Presence of anti body to SM nuclear } \\
\text { antigen OR } \\
\text { ( c ) Positive finding of antiphospholipid } \\
\text { antibodies based on } \\
\text { 1. an abnormal serum level of lgG or IgM } \\
\text { anticardiolilin } \\
\text { 2. antibodies, ( } 2 \text { ) a positive test result for lupus } \\
\text { anticoagulant using a standard method, or } \\
\text { ( } 3 \text { ) a false-positive serologic test for syphilis } \\
\text { known to be positive for at least } 6 \text { months } \\
\text { and confirmed by treponema pallidum } \\
\text { immobilization or fluorescent treponemal } \\
\text { antibody absorption test }\end{array}$ \\
\hline ANA & $\begin{array}{l}\text { Abnormal titer of ANA by immuno florescence } \\
\text { or equivalent assay } \\
\text { At any point in the absence of drugs known } \\
\text { to be associated with drug- induced lupus } \\
\text { syndrome }\end{array}$ \\
\hline
\end{tabular}

The two cases presented here had malar rash which is consistent with the diagnosis of lupus. The first patient had painful intraoral lesions the painful joints, the pleural effusion was consistent with the serositis of lupus the seizures and the finding of cerebral atrophy on the brain MRI in our case is consistent with the presence of lupus cerebritis. The first patient had severe pancytopenia and the elevated ESR the result of the serologic tests show the severity of her illness.

The second patient had a different presentation with livedo reticularis, was very photosensitive and she had skin lesions on the both legs which were difficult to close, all these are consistent lupus vasculitis. The presence of the proteinuria in the first urinalysis is consistent with early lupus nephritis. The serologic findings with the very low complement level are typical of active systemic lupus erythematosus ${ }^{2}$.

\section{Treatment}

The discovery and the use of corticosteroids in the 1950, Renal Dialysis in the 1960 and the cyclophosphamide in the 1970 were the milestones in the treatment of SLE.

The goals of therapy are the reduction of both autoimmunity and target organ damage from inflammation and injury.

Corticosteroids, hydroxychloroquine and aspirin are the only three drugs, currently approved by the US Food Drug Administration for use in SLE.

The treatment is based on preventive measures, reversal of inflammation and prevention of organ impairment. An effective therapeutic regiment first requires the accurate determination of both, disease activity and severity ${ }^{3}$. The markers of activity are the combination of the clinical history, physical examination, organ specific functional tests and serologic studies.

General Management: Smoking cessation, good diet and nutrition:

The patients must have a balanced diet consisting of carbohydrates, proteins and fat. Some physicians recommend fish oil. Low-fat diet recommended to patients who have presented hyperlipidemia due to nephritic syndrome or glucocorticoid therapy.

Patients on long-term glucosteroids and postmenopausal women should take vitamin $D$ plus Calcium; for prevention and treatment of glucocorticoid induced osteoporosis.

\section{Conclusion}

SLE with its multi-organ effects may easily fall into the categories diseases of masters of mimicry. As has been shown by the two cases the need for accurate diagnosis and aggressive therapyand meticulous follow up can positively influence the disease outcome.

\section{References}

1. John H. Klippel Primer on the Rheumatic Diseases (thirteenth edition)

2. Von Feldt, JM. Systemic Lupus Erythematosus. Recognizing its various presentations. Post grad. Med. 1995; 97-99

3. Bootsma, H, Spronk, PE, TerBorg, EJ, et al. The Predictive Value Of Fluctuations In IgM And IgG Class Anti-dsDNA antibodies for relapses in systemic lupus erythematosus. A prospective long term observation. Ann Rheum Dis 1997; 56:661

4. Gladman, DD, Ibanez, D, Urowitz, MB. Systemic Lupus Erythematosus Disease Activity Index 2000. J Rheumatol 2002; 29:288. 